\title{
EFFECT OF WATER REQUIREMENTS AND NITROGEN FERTELIZATION ON MAIZE CROP PRODUCTIVITY IN CLAY SOIL
}

\author{
Mansour H. El-Bakhshwan ", Hussien A. Elsoury ${ }^{1}$, \\ Mohamed M. N. Khalil ${ }^{1}$ and Hamed M. El-Kouny ${ }^{2}$
}

ABSTRACT

Field experiment was carried out at tractors and farm machinery testing \&research station, Alex. Governorate, Egypt, during the summer season of 2017, to evaluate the effect of three levels of water requirements and two sources of nitrogen fertilization on the vegetation growth and yield of maize (zea maize L.) and some soil properties. The experiment included nine treatments which were arranged in a split plot based on RCBD design, and replicated three times. Main plots consisted of $100 \%$ of water requirements for maize plant [100\%WR], $80 \%$ of water requirements [80\%WR] and $60 \%$ of water requirements [60\%WR], while three fertilization types: Organic manure [OM] contains 120 unit's organic nitrogen [ON], Mineral nitrogen fertilizer $\left[M_{n} F\right]$ contains 120 unit's mineral nitrogen $\left[M_{n} N\right]$, Mixture of $[O M] \&\left[M_{n} F\right]$ with proportion (1:1) contains 120 unit's nitrogen $\left[\mathrm{XOM}_{n}\right]$, as well as control were arranged in sub plots.

Recommended fertilization was applied according to Agriculture ministry system. Measured parameters were number of rows in one ear, number of grains in each row, weight of 100- kernel (g), grain yield and stover yield (Ton/Fed). Statistical analysis of the experimental data indicated that, the treatment $[80 \% \mathrm{WR}]+\left[\mathrm{XOM}_{n}\right]$ was the greatest significant of $T-N, A v-N$, $E C, T-P, K b$ and $A v-W$ in comparing with all treatments. Addition [XOM ${ }_{n}$ ] and $(80 \%$ WR) resulted in high significant values of number of rows in one ear, number of grains in each row, weight of 100-grain (g), grain yield and stover yield ( $\mathrm{kg} / \mathrm{fed})$.

Keywords: maize, irrigation, organic manure, mineral fertilizer, compost.

1- Agricultural Engineering Research Institute, Agriculture Research Centre, Egypt.

2- Soil water and environment Research Institute, Agriculture Research Centre, Egypt.

bakhshwan@yahoo.com 


\section{INTRODUCTION}

$\mathrm{M}$ aize is one of the most widely grown cereals in the world and has great significance as human food, animal feed and raw material. In most developing countries, about 50 to 55 percent of the total maize production is consumed as food (Arun Kumar et al., 2007). Maize has high production potential especially under irrigated condition when compared to any other cereal crop. The productivity of maize largely depends on its nutrient requirement and management particularly that of nitrogen, phosphorus and potassium (Arun Kumar et al., 2007).

Mehanna et al (2013) carried out field experiments on maize (Zea nays L.) in sandy loam soil to investigate the effects of irrigation frequency under surface and subsurface drip irrigation systems on growth parameters, grain yield, N, P and K uptakes, and water use efficiency (WUE). Results indicated that the highest values of maize growth parameters were gained when irrigating plants with $100 \%$ of the ETc $\left(2500 \mathrm{~m}^{3} / \mathrm{fed} .=\right.$ high frequency $)$ treatment by using subsurface drip irrigation system. On the contrary, the lowest values appeared by irrigating plants by (70 \% of ETc $=$ low frequency) under surface drip irrigation system. It can be concluded that, subsurface drip irrigation was considered to be best irrigation system particularly in newly reclaimed soil. Addition of $80 \%$ of ETc treatment gave highest WUE, nitrogen uptake (under surface system) and high grain yield without significant difference compared to $100 \%$ of ETc. So, it's wise to irrigate maize with $80 \%$ of ETc as recommended for attaining maximized yield and WUE especially in arid and semiarid regions.

Hammad et al. (2011) studied the effect of irrigation regimes and nitrogen rates on growth and yield of maize hybrid at Agronomic Research Area under semiarid conditions of Pakistan. Results showed that water and nitrogen are the most important factors, play their role in better growth and yield of maize, where maximum leaf area index (4.92), number of grains per cob (490), grain yield $\left(8.49 \mathrm{t} \mathrm{ha}^{-1}\right)$ and harvest index $(47.73 \%)$ were achieved in treatment with nitrogen rate $250 \mathrm{~kg} \mathrm{ha}^{-1}+$ irrigation regime I1 (eight irrigations) while the highest biological yield $\left(17.97 \mathrm{t} \mathrm{ha}^{-1}\right)$ was recorded with nitrogen rate $300 \mathrm{~kg} \mathrm{ha}^{-1}$ treatment with 
the I1 irrigation regimes. The minimum1000-grains weight (314 g), biological yield $\left(12.48 \mathrm{t} \mathrm{ha}^{-1}\right)$ and grain yield $\left(4.67 \mathrm{t} \mathrm{ha}^{-1}\right)$ were recorded in the combination of $\mathbf{I} 2$ irrigation regime (six irrigations, two missed at vegetative stage) and $150 \mathrm{~kg} \mathrm{ha}^{-1}$ ), treatments. Water stress at six and twelve leaves stage simultaneously decreased grain yield $30 \%$ while water stress at grain filling stage decreased $20 \%$ yield. Reddy (2006) said that Maize requires $600-700 \mathrm{~mm}$ water for optimum growth and yield depending upon climatic conditions. Paudyal et al. (2001) reported that water deficiency at any growth stage of maize reduces growth and productivity of the crop. To cope with the water shortage, it is necessary to adopt water saving agriculture countermeasures as efficient use of irrigation water. Zaman et al. (2001) concluded that irrigation scheduling for crops, using advanced irrigation methods (sprinkler and drip) and improved water management practices are very important to water saving. El-Sherbiny et al, (2014) indicated that the fertilizer nitrogen balance of both organic compost and microbial inoculation had reduced the dependence on mineral fertilizer and in the same time minimized the losses of nitrogen fertilizer. Sinkevičienė et al. (2009) said that the application of organic mulches as a soil cover is effective in improving the quality of soil and increasing crop yield, especially in organic farming. palm et al (2001) mentioned that the developed countries of world faces a great problem either in the human health or in the environmental due to the excessive uses of mineral or chemical fertilizers, especially those of nitrogenous of high yielding crop cultivates under assured perennial irrigation. So that, there is a renewed interest in organic recycling to nutrients supply as well as to improve the neutral organic wastes to soils has gained momentum in the recent past and agriculture.

Improving water use efficiency requires a development of satisfactory means to estimate crop water requirements or evapotranspiration (ETO). In Egypt great attention has been paid to increase corn (maize) production as one of the main cereal crops.

The objective of this present work is to get the best irrigation quantity and fertilization source application which is more efficiency for maize production. 


\section{MATERIALS AND METHODS}

\section{1- Site Description and Experimental Design:}

Field experiment was carried out during the summer season of 2017 at Tractors and Farm machinery Testing \& Research Station at Sabahia, Alexandria Governorate, Egypt, to study the effect of water requirements and nitrogen fertilization on the vegetation growth and yield of maize ((Zea mays L.), as well as some physico-chemical properties of soil. The experiment was performed in split plot design with three replicates.

The main and sub main treatments were as follows:

A- Quantities of water applied:

$1-100 \%$ of water requirements for maize plant $\left[100 \% \mathrm{~W}=4000 \mathrm{~m}^{3} / \mathrm{Fed}\right]$,

2- $80 \%$ of water requirements for maize plant [ $80 \% \mathrm{WR}]$,

3- $60 \%$ of water requirements for maize plant [60\% WR].

B- Types of fertilizers:

1- Organic manure $[\mathrm{OM}]$ contains 120 units' organic nitrogen [ON ],

2- Mineral nitrogen fertilizer $\left[\mathrm{M}_{\mathrm{n}} \mathrm{F}\right]$ contains 120 units mineral nitrogen $\left[\mathrm{M}_{\mathrm{n}} \mathrm{N}\right]$,

3- Mixture of Organic manure and Mineral nitrogen fertilizer [XOM at rang (1:1) contains 120 units nitrogen, as well as control treatment.

The experimental field area was $180 \mathrm{~m} 2$, divided into 36 plots, planned by hand at $1.0 \mathrm{~m}$ row spacing at $0.3 \mathrm{~m}$ soil depth. Each plot area was about $3 \mathrm{~m}$ long and 1 plant rows wide, and total space of about $2.0 \mathrm{~m} 2$ was left surrounding all directions of each plot. The irrigation water quantity was applied though a furrow irrigation system, the field was irrigated every a 7-9 day interval. Weeds removed by hand in all plots and protection against diseases were practiced whenever it was necessary.

\section{Soil Analysis:}

Soil samples from surface layer $(0-30 \mathrm{~cm})$ were collected for determining the soil physical and chemical properties according to the standard methods outlined by black et. al. (1965), Jackson (1973) and page et al. (1982). Total nitrogen $(\mathrm{T}-\mathrm{N})$ and Available nitrogen $(\mathrm{Av}-\mathrm{N})$ were extracted and determined according to the methods under taken by Soltanpour and Schwab (1977) and Jackson (1973). Data were represented in Table 1. 
Table (1). Some physical and chemical properties of the tested soil.

\begin{tabular}{|c|c|}
\hline properties & The values \\
\hline \multicolumn{2}{|c|}{ Chemical properties } \\
\hline PH (1:2.5) soil : water & 7.95 \\
\hline EC,d S m-1 (1:2.5) & 2.60 \\
\hline Soluble Cations (meg/L) & \\
\hline $\mathrm{Na}, \mathrm{K}^{+}, \mathrm{Ca}^{+} 2, \mathrm{Mg}^{+} 2$ & $4.80,0.10,11.5$ and 5.66 respectively \\
\hline Soluble anions $(\mathrm{meg} / \mathrm{L})$ & \\
\hline $\mathrm{HCO} 3, \mathrm{CL}^{+}, \mathrm{SO}^{2} 4$ & $7.00,5.50$ and 9.66 respectively \\
\hline Total nitrogen, \% (T.N) & 0.10 \\
\hline Available nitrogen ,ppm (Av.N) & 24.24 \\
\hline Total Carbonat \% $\left(\mathrm{T}^{-\mathrm{CaCo}_{3}}\right)$ & 4.85 \\
\hline $\begin{array}{l}\text { Cation exhangable capacity } \\
\text { (CEC) meg/100 soil }\end{array}$ & 9.55 \\
\hline \multicolumn{2}{|c|}{ Physical properties } \\
\hline Total porosity, (T.P) $\%$ & 51.25 \\
\hline $\begin{array}{l}\text { Hydraulic Conductively (HC) } \\
(\mathrm{cm} / \mathrm{h})\end{array}$ & 01.75 \\
\hline Available water, (Av.W) \% & 17.95 \\
\hline Texture class & Sand clay loam \\
\hline $\begin{array}{l}\text { Particle size distribution, \% } \\
\text { Sand, Silt, Clay }\end{array}$ & $44.20,26.10$ and 29.76 respectively \\
\hline Soil bulk density $\left(\mathrm{gm} / \mathrm{cm}^{3}\right)$ & 1.31 \\
\hline
\end{tabular}

\section{Where:}
$\mathrm{T} . \mathrm{N}=$ total nitrogen
T. $\mathrm{CaCo}_{3}=$ Total carbonat
Av. $\mathrm{N}=$ Available nitrogen
$\mathrm{CEC}=$ Cation exhangaable capacity

\section{Compost fertilizer analysis:}

The source of organic manure (compost fertilizer) was produced and analyzed in Saline and Alkaline research Lab Alexandria-. The 
characteristics of organic manure were determined according to Muthur et al.(1993) and El-Kouny (1991) and displayed in table 2.

Table (2) Chemical and Physical properties of compost.

\begin{tabular}{|l|c|}
\hline \multicolumn{1}{|c|}{ Properties } & Values \\
\hline Baulk density B.D $\left(\mathrm{kg} / \mathrm{m}^{3}\right)$ & 630 \\
\hline Moisture content M.C $(\%)$ & 27 \\
\hline PH $(1: 5)$ & 8.4 \\
\hline EC $(1: 5) d S m-1$ & 6.3 \\
\hline Saturation percentage S.P(\%) & 250 \\
\hline Total nitrogen T.N $(\%)$ & 2.06 \\
\hline Total carbon T.C $(\%)$ & 31.00 \\
\hline Organic matter O.M $(\%)$ & 54.00 \\
\hline Mineral ash ASH $(\%)$ & 46.00 \\
\hline C/N ratio & $15: 1$ \\
\hline Na cl $(\%)$ & 2.10 \\
\hline Humic substances H.S (\%) & 16.20 \\
\hline Total phosphorous T.P $(\%)$ & 1.01 \\
\hline Total potassium T.K $(\%)$ & 1.20 \\
\hline Fe (ppm) & 920 \\
\hline Ma (ppm) & 150 \\
\hline Cu (ppm) & 41 \\
\hline Zn (ppm) & 240 \\
\hline
\end{tabular}

\section{Available $\mathrm{N}$ were determined according to Black (1965)}

The organic manure were added to lasted soil during the soil preparation $25 \mathrm{~cm}$ depth of the top soil) while mineral fertilizer was added at twice, the first after 2 weeks while the second was added after 6 weeks from planting. The normal fertilization from $\mathrm{N}, \mathrm{P}$ and $\mathrm{K}$ were added according to Agriculture ministry system. All treatments were arranged in complete randomized blocks design (RCBD) with three replicates.

\section{Plant growth measurements:}

Some physical and chemical characteristics of maize grains, stover and plant stem were carried out as the following: 


\section{Measurements of maize seeds:}

Five samples of maize ear were randomly taken from each treatment to evaluate the following physical characteristics: weight of ear, number of seeds per ear, number of rows per ear and number of seeds per row in ear. Evaluation of T-N, Av-N :

A plant sample consists of five plants was randomly chosen from the three rows for chemical determination ( $\mathrm{T}-\mathrm{N}, \mathrm{Av}-\mathrm{N})$, plant samples were cut off at the ground level after 120 days from planting. T-N in seeds was estimated using nitrogen micro kjeldahl apparatus as described in A.O.A.C 1995).

\section{Water use efficiency (WUE):}

Water use efficiency is the measure of a cropping system's capacity to convert water into plant biomass or grains. Water use efficiency (WUE) was determined according to Michael (1978) by using the following equation,

Water use efficiency $=$ Crop yield, $\left(\mathrm{kg} \mathrm{fed}^{-1}\right) /$ Water applied, $\left(\mathrm{m}^{3} \mathrm{fed}^{-1}\right)$

\section{Statistical analysis:}

All data were subjected to the statistical analysis according to Sedecor, and Cochran (1980) to define the least significant difference test (L.S.D. at $\mathrm{p}=0.05$ level)

\section{RESULTS AND DESCUSSION}

\section{Soil characteristics:}

Effect of water requirements (WR) and mineral nitrogen fertilization $\left[\mathrm{M}_{\mathrm{n}} \mathrm{F}\right]$ on total nitrogen (T.N) and available nitrogen (Av.N) and some soil sample properties collected from rhizosphere area of grown maize plant after harvesting are showed in table 3. The obtained data showed, the effect of (W.R) and fertilizer types added as organic fertilizer (ON), mineral fertilizer $\left(\mathrm{M}_{\mathrm{n}} \mathrm{N}\right)$ and mixture of organic and mineral $\left(\mathrm{XOM}_{\mathrm{n}}\right)$ respectively on soil, which caused a pronounced amelioration effect on available nitrogen (Av.N), total nitrogen (T.N) and some soil properties as, soil PH, soil EC, total porosity (TP), available water (Av.W) and hydrolic conductivity (HC) as a shown in table (3). Data illustrated in table (3) showed a progressive significant increase in the all treatments compared to the control treatment. The greatest mean value of available nitrogen (Av.N) was $126.86 \mathrm{ppm}$ with organic fertilizer $(\mathrm{ON})$ and $80 \%$ 
water requirements (WR). The positive response of applied organic manure and mineral fertilizer as well as water requirements was displayed by many authors such as Mohamed (2006) and beside its beneficial effect on some soil chemical these finding were confirmed by the results founded by Saker et al (1992).

Table (3): Effect of water requirements (WR) and nitrogen fertilization types on soil properties after harvesting.

\begin{tabular}{|c|c|c|c|c|c|c|c|c|}
\hline \multicolumn{2}{|c|}{$\begin{array}{l}\text { Properties } \\
\text { treatments }\end{array}$} & $\begin{array}{c}\text { EC,dS } \\
\text { m-1 } \\
1: 2.3 \\
\end{array}$ & $\begin{array}{c}\text { PH } \\
1: 2.5\end{array}$ & $\begin{array}{c}\text { Av.W } \\
\%\end{array}$ & $\begin{array}{l}\text { T.P } \\
\%\end{array}$ & $\begin{array}{c}\mathrm{Kb} \\
\mathrm{Cm} / \mathrm{h}\end{array}$ & $\begin{array}{c}\text { T.N } \\
\%\end{array}$ & $\begin{array}{l}\text { Av.N } \\
\text { Ppm }\end{array}$ \\
\hline \multicolumn{2}{|c|}{ Control } & 2.46 & 7.91 & 15.52 & 51.60 & 1.79 & 0.11 & 75.0 \\
\hline \multirow{3}{*}{$\begin{array}{c}100 \% \\
W\end{array}$} & $\mathbf{O N}$ & 2.60 & 7.71 & 20.21 & 56.21 & 2.81 & 1.50 & 102.12 \\
\hline & $\mathbf{M}_{\mathbf{n}} \mathbf{N}$ & 2.80 & 7.89 & 19.25 & 54.25 & 2.4 & 1.30 & 107.21 \\
\hline & $\mathbf{X O M}_{n}$ & 2.10 & 7.62 & 22.62 & 56.95 & 2.59 & 1.55 & 122.35 \\
\hline \multirow{3}{*}{$\begin{array}{c}80 \% \\
W\end{array}$} & ON & 2.20 & 7.60 & 22.02 & 66.55 & 2.78 & 1.55 & 105.16 \\
\hline & $\mathbf{M}_{\mathbf{n}} \mathbf{N}$ & 2.56 & 7.86 & 19.89 & 53.99 & 2.86 & 1.40 & 110.52 \\
\hline & $\mathbf{X O M}_{n}$ & 2.01 & 7.35 & 24.25 & 56.99 & 2.95 & 1.95 & 126.85 \\
\hline \multirow{3}{*}{$\begin{array}{c}60 \% \\
W\end{array}$} & ON & 2.60 & 7.70 & 18.11 & 54.25 & 2.85 & 1.50 & 102.21 \\
\hline & $\mathbf{M}_{\mathbf{n}} \mathbf{N}$ & 2.40 & 7.85 & 17.22 & 53.24 & 2.71 & 1.40 & 108.95 \\
\hline & $\mathbf{X O M}_{n}$ & 2.30 & 7.50 & 19.83 & 53.80 & 2.92 & 1.55 & 121.26 \\
\hline \multicolumn{2}{|c|}{ L.S.D at 0.05} & 1.89 & 0.068 & 0.18 & 1.81 & 0.21 & 0.19 & 8.92 \\
\hline
\end{tabular}

Point of view, the combined treatment of mix organic manure and mineral nitrogen fertilizer and $80 \%$ of water requirement (WR) which is considered the superiority over than the other treatments was great enough to reach the level of significance under the prevailing conditions of current experiment. Also, the effect of water requirement (WR) and nitrogen fertilization to the experimental soil under cultivation with maize caused a marked effect in some of the studied soil characters, i.e. total porosity, hydraulic conductivity and available water range as shown in table (3). The greatest mean value for the treatment $80 \%$ of water requirement (WR) and nitrogen fertilization were $56.99 \%, 2.95 \mathrm{~cm} / \mathrm{h}$ and $24.25 \%$ for total porosity, hydraulic conductivity and available water respectively (Ewees et al 2008). Table (3) represent the mean values of 
total nitrogen (T.N) and available nitrogen ( Av.N) in all treatments in soil. Data indicated a progressive significant increase in all treatments where the greatest mean value of total nitrogen (T.N) and available nitrogen ( Av.N) were $1.95 \%$ and 126.85 ppm respectively with $80 \%$ of water requirements (WR) and mixture of organic manure and mineral fertilizer $\left(\mathrm{XOM}_{\mathrm{n}}\right)$. The lowest mean values were with control, (Abou ELMaged et al (2006). The obtained data in table (3) also showed significant differences between all treatments mean values in soil $\mathrm{PH}$ and EC. Hence from the economical point of view, the combined treatment of $80 \%$ of water requirements (WR) and mixture of organic manure and mineral fertilizer $\left[\mathrm{XOM}_{n}\right]$ is considered the superiority over than the all treatments. It was great enough to reach the level of significance under prevailing condition of current experiment.

Also, this treatment showed a distinct effect on total porosity (TP), hydraulic conductivity (HC) and available water (Av.W), as shown in table(3), the greatest mean values were $56.99 \%, 2.95 \mathrm{~cm} / \mathrm{h}$ and $24.23 \%$ for total porosity (TP), hydraulic conductivity (HC) and available water (Av.W) respectively (Ewees et al 2008).

\section{Grain and stover yield:}

Data illustrated in table (4) showed that grain and stover yield responded significantly to $100 \%$ of water and mixing of organic mineral fertilizer $\left(\mathrm{XOM}_{\mathrm{n}}\right)$. The highest grain and stover yield were 2.80 and 7.270 ton/Fed respectively. On the other hand result showed differences between $80 \%$ of water with mixing of organic mineral fertilizer $\left[\mathrm{XOM}_{\mathrm{n}}\right]$ treatment and other treatments due to interaction of organic nitrogen fertilizer [ON] and mineral nitrogen fertilizer $\left[\mathrm{M}_{\mathrm{n}} \mathrm{N}\right]$ with $80 \%$ of water. These results are agreed with those of Bohman et al. (2004).

\section{Kernel weight:}

Data illustrated in table (4) showed that 100- kernel weight (g) and kernel weight per ear $(\mathrm{g})$ were the heaviest with $80 \%$ of water and organic mineral fertilizer $\left[\mathrm{XOM}_{\mathrm{n}}\right] 39.40$ and $129.58 \mathrm{~g}$ respectively. Control treatment was not significant for kernel weight, where the mean value for control was significantly less than other treatments (Omar 2001). 
Table (4): Effect of water requirements (WR) and nitrogen fertilization types on some growth characteristics of maize crop.

\begin{tabular}{|c|c|c|c|c|c|c|c|}
\hline \multicolumn{2}{|c|}{ Parameters } & $\begin{array}{l}\text { No.of } \\
\text { raw in } \\
\text { ear } \\
\text { (M1) }\end{array}$ & $\begin{array}{c}\text { No.of } \\
\text { kernels } \\
\text { in raw } \\
\text { (M2) }\end{array}$ & $\begin{array}{l}\text { Weight } \\
\text { of } 100 \\
\text { kernels } \\
\text { (K) gm }\end{array}$ & $\begin{array}{l}\text { Grains } \\
\text { yield(Wn) } \\
\text { (ton/Fed) }\end{array}$ & $\begin{array}{c}\text { Stover } \\
\text { yield(W2) } \\
\text { (ton/Fed) }\end{array}$ & $\begin{array}{l}\text { Weight } \\
\text { of kernel } \\
\text { in ear } \\
\text { (Wn)gm }\end{array}$ \\
\hline \multicolumn{2}{|c|}{ Control } & 12.33 & 21.67 & 30.12 & 1.850 & 2.787 & 96.32 \\
\hline \multirow{3}{*}{$\begin{array}{c}100 \% \\
\text { W }\end{array}$} & ON & 14.33 & 24.67 & 33.89 & 2.100 & 3.566 & 200.24 \\
\hline & $\mathrm{M}_{\mathrm{n}} \mathrm{N}$ & 14.00 & 41.67 & 30.54 & 2.200 & 3.800 & 178.13 \\
\hline & $\mathbf{X O M}_{n}$ & 13.33 & 40.00 & 31.02 & 2.500 & 3.950 & 165.44 \\
\hline \multirow{3}{*}{$\begin{array}{c}80 \% \\
\text { W }\end{array}$} & ON & 13.67 & 31.00 & 30.61 & 2.500 & 5.249 & 129.67 \\
\hline & $\mathrm{M}_{\mathrm{n}} \mathrm{N}$ & 14.00 & 34.67 & 30.64 & 2.400 & 5.589 & 148.71 \\
\hline & $\mathbf{X O M}_{n}$ & 14.67 & 45.33 & 39.40 & 2.800 & 7.270 & 129.58 \\
\hline \multirow{3}{*}{$\begin{array}{c}60 \% \\
\text { W }\end{array}$} & $\mathbf{O N}$ & 13.33 & 34.33 & 33.20 & 2.100 & 3.100 & 152.00 \\
\hline & $\mathrm{M}_{\mathrm{n}} \mathrm{N}$ & 12.33 & 30.33 & 32.44 & 2.110 & 3.100 & 121.36 \\
\hline & $\mathbf{X O M}_{n}$ & 14.00 & 43.33 & 31.75 & 2.300 & 3.250 & 210.52 \\
\hline \multicolumn{2}{|c|}{ L.S.D at 0.05} & 0.700 & 0.900 & 0.990 & 0.050 & 0.070 & 1.100 \\
\hline
\end{tabular}

Ear kernel number:

The mean values of ear kernel number and number of row per ear were higher in the treatment of $80 \%$ of water and organic mineral fertilizer $\left[\mathrm{XOM}_{\mathrm{n}}\right]$ than other treatments. This treatment was significantly higher than other treatments, which were 14.67 and 45.33 respectively, which agreed with studies of Balsarof and Mohile (1994) and Barsoom (1998).

Data illustrated in table (5) showed that T-N concentrations (100\%) of grain and straw, and $\mathrm{N}$ uptake in Fadden $(\mathrm{kg})$ were higher with $80 \%$ of water requirements and organic mineral fertilizer $\left[\mathrm{XOM}_{\mathrm{n}}\right]$, which were $1.35 \%, 0.19 \%$ and $49.50 \mathrm{~kg} / \mathrm{Fed}$ respectively.

The higher water use efficiency was $0.96 \mathrm{~kg} / \mathrm{m}^{3}$ gained from the treatment $\left[60 \% \mathrm{~W}, \mathrm{XOM}_{\mathrm{n}}\right]$, while the lowest WUE was $0.53 \mathrm{~kg} / \mathrm{m}^{3}$ with the treatment $[100 \% \mathrm{~W}, \mathrm{ON}]$. It is logically known that the WUE increases when the amount of applied water decreases, but the crop yield may be decreased. inspecting all the efficiency results of irrigation with the crop yields, it was found that WUE $0.96 \mathrm{~kg} / \mathrm{m}^{3}$ corresponds to the yield 2300 $\mathrm{kg} / \mathrm{Fed}$ while the WUE $0.88 \mathrm{~kg} / \mathrm{m}^{3}$ corresponds to the highest production $2800 \mathrm{~kg} / \mathrm{Fed}$ with water irrigation $80 \%$. 
Table (5): Effect of water requirements (WR) and nitrogen fertilization types on T-N concentrations (100\%) of grain and straw and $N$ uptake in Fadden (kg).

\begin{tabular}{|c|c|c|c|c|}
\hline \multicolumn{2}{|c|}{ Parameters treatments } & $\begin{array}{c}\text { T.N } \\
\text { Conc. }(\%) \text { in } \\
\text { grains }\end{array}$ & $\begin{array}{l}\text { N. uptake } \\
\text { (kg/feddan) }\end{array}$ & $\begin{array}{c}\text { T.N } \\
\text { Conc. }(\%) \\
\text { in stover }\end{array}$ \\
\hline \multicolumn{2}{|c|}{ Control } & 0.85 & 21.00 & 0.06 \\
\hline \multirow{3}{*}{$100 \% W$} & ON & 1.1 & 35.2 & 0.1 \\
\hline & $\mathbf{M}_{\mathbf{n}} \mathbf{N}$ & 1.01 & 36.5 & 0.11 \\
\hline & $\mathbf{X O M}_{n}$ & 1.2 & 38.9 & 0.13 \\
\hline \multirow{3}{*}{$80 \% \mathrm{~W}$} & ON & 1.25 & 45.9 & 0.11 \\
\hline & $\mathbf{M}_{\mathrm{n}} \mathbf{N}$ & 1.11 & 46.2 & 0.12 \\
\hline & $\mathbf{X O M}_{n}$ & 1.35 & 49.5 & 0.19 \\
\hline \multirow{3}{*}{$60 \% \mathrm{~W}$} & ON & 1.1 & 38.5 & 0.1 \\
\hline & $\mathbf{M}_{\mathbf{n}} \mathbf{N}$ & 1.03 & 39.09 & 0.11 \\
\hline & $\mathbf{X O M}_{n}$ & 1.25 & 39.02 & 0.14 \\
\hline \multicolumn{2}{|c|}{ L.S.D at 0.05} & 0.11 & 4.3 & 0.11 \\
\hline
\end{tabular}

Water use efficiency (W.U.E):

Table 6 indicates the average values of WUE obtained in all treatments.

Table (6): Average values of water use efficiency.

\begin{tabular}{|l|c|c|c|}
\hline Treatment & $\begin{array}{l}\text { Yield } \\
\mathrm{kg} / \mathrm{fed}\end{array}$ & $\begin{array}{l}\text { Water irrigation, } \\
\mathrm{m}^{3} / \mathrm{fed}\end{array}$ & $\begin{array}{l}\text { W. U. E. } \\
\mathrm{kg} / \mathrm{m}^{3}\end{array}$ \\
\hline $100 \% \mathrm{~W}, \mathrm{ON}$ & 2100 & 4000 & 0.53 \\
\hline $100 \% \mathrm{~W}, \mathrm{M}_{\mathrm{n}} \mathrm{N}$ & 2200 & 4000 & 0.55 \\
\hline $100 \% \mathrm{~W}, \mathrm{XOM}_{\mathrm{n}}$ & 2500 & 4000 & 0.63 \\
\hline $80 \% \mathrm{~W}, \mathrm{ON}$ & 2500 & 3200 & 0.78 \\
\hline $80 \% \mathrm{~W}, \mathrm{M}_{\mathrm{n}} \mathrm{N}$ & 2400 & 3200 & 0.75 \\
\hline $80 \% \mathrm{~W}, \mathrm{XOM}_{\mathrm{n}}$ & $\mathbf{2 8 0 0}$ & $\mathbf{3 2 0 0}$ & $\mathbf{0 . 8 7 5}$ \\
\hline $60 \% \mathrm{~W}, \mathrm{ON}^{2}$ & $\mathbf{2 1 0 0}$ & $\mathbf{2 4 0 0}$ & $\mathbf{0 . 8 7 5}$ \\
\hline $60 \% \mathrm{~W}, \mathrm{M}_{\mathrm{n}} \mathrm{N}$ & 2110 & 2400 & 0.879 \\
\hline $60 \% \mathrm{~W}, \mathrm{XOM}_{\mathrm{n}}$ & $\mathbf{2 3 0 0}$ & $\mathbf{2 4 0 0}$ & $\mathbf{0 . 9 5 8}$ \\
\hline Control & 1850 & 4000 & 0.46 \\
\hline
\end{tabular}




\section{CONCULATIONS}

\section{The obtained results indicated the following:}

1- $80 \%$ of water requirements for maize plant $(80 \% \mathrm{WR})$ with organic mineral fertilizer $\left[\mathrm{XOM}_{\mathrm{n}}\right]$ treatment was the greatest significant of total nitrogen concentrations (T.N), available nitrogen (Av.N), EC (lowest value), total porosity (T.P), Kb and available water (Av.W) of all other treatments as well as control treatment.

2- Addition of organic mineral fertilizer $\left[\mathrm{XOM}_{\mathrm{n}}\right]$ and $(80 \% \mathrm{WR})$ resulted in high significant values of total yield, ear kernel number and number of rows per ear.

3- The best WUE $0.88 \mathrm{~kg} / \mathrm{m}^{3}$ resulted with water irrigation $80 \%$

\section{REFERENCES}

A.O. A.C. (1995), Association of official Analysis Chemists official methods of analysis, 15 th ed., Washington. U. S. A.

Abou El-maged. M.M., A.M.,El bassiony and Z. F. Fawzy. (2006) Effect of organic manure with or without chemical fertilizers on growth yidd and quilety of some varieties of broccoli plants. j. Appll. Sci. res. 2 (16): 791-798.

Arun Kumar, M. A., S. K. Gali and N. S. Hebsur (2007). Effect of Different Levels of NPK on Growth and Yield Parameters of Sweet Corn. Karnataka J. Agric. Sci., 20 (1) p 41 - 43.

Bohman,E, D.Gining and J.E.Gilley (2004) residual effects of manure and compost application on production and soil properties. Agron. J. 96: 442-447.

Balsarof, M.D. and A.V. mohile, (1994), effect of fym and prite on nutrient uptake and yield of crop in black calcareous soil $\mathrm{j}$. Maharashtra. Agric. U niv 19 (1), 125.

Barsoom, S.W.(1998) Comparative effect of inoculation will Av, my corrhizal fungi and organic matter addition on phosphorus and uptake by maize. Egypt. J. soil Sci. 38(1-4)12. 
Black, C.A., D.D., Easm L. E.,inager, J. I.White, and F. E.Clark, (1965). Methods of soil Analysis .Part 11.Agron.ASA and SSSA,Madison,Wl.

El-kouny, H. M. (1991)Evaluation of compost production and its properties with special reference to composts extrad. PHD Thesis faculty of agriculture, Alexandria university.

El-Sherbiny A. E;; Y. G. M. Galal,; S. M. Soliman;, S. M. Dahdouh1; M. M. Ismail and A. Fathy (2014), Fertilizer Nitrogen Balance in Soil Cultivated with Pea (Pisum sativum L.) under Bio and Organic Fertilization System using 15N Stable Isotope 4th Int. Con. Rad. Res. Appl. Sci., Taba, Egypt (2014) PP. $75: 86$

Ewees, M.A., A.sh. Osman and D.M. El Sowfy,(2008) significance of applied organic manure combined with $\mathrm{N}$ - mineral fertilizer. Egypt.J.Soil Sci.48, No.3 pp.347-360

Hammad H. M., A. Ahmad D,F. Azhar, T. Khaliq, A. Wajid, W. Nasim, AND W. Farhad (2011). Optimizing water and nitrogen requirement in maiz (Zea Mays L.) under semi arid conditions of Pakistan. Pak. J. Bot., 43(6): 2919-2923.

Jackson, M.L.(1973) Soil chemical analysis prentice-hall of sndian private limited. New Delhi.

Muthur, S. P., H. Dinel, G. Owen, M. Schnitzer and J. Dugan (1993). Metermination of compost bio maturely, optical density of water extrados of compost as a relation of their maturely. Biological agricultural and horticulture. Vol.10, pp. 87-108.

Mehanna H.M., 1Hussein M.M. and Nesreen H. Abou-Baker (2013). The Relationship between Water Regimes and Maize Productivity under Drip Irrigation System: A Statistical Model. Journal of Applied Sciences Research, 9(6): 3735-3741.

Methods of Soil Analysis Amer. Soc. Agron. Inc.pub. Madison, wisconsir.USA. 
Michael, A. M. (1978). Irrigation theory and practice. Vikas phb. House PVTLTD New Delhi, Bombay: 360 p.

Mohamed, S. A.(2006). A compression between the effect of different source of organic and mineral fertilizes on growu, anatomical structure yield and chemical composition of Roselle (H. biscus sabdriffall) plant. The second conference on farm Integrated pest Management. Jan, 16-18, 2006, Fayoum. Egypt.

Omar, M.A. (2001). Evaluation of some new maize cullivars under different agricultural practies. Ph.D. Thesis, Fac. Of Agric. Kafer elsheikh, Tanta unive., Egypt.

Page, A. I., R. H. Miller, and Keeney (1982), methods of soil analysis, part 2: chemical and microbiological properties, 2 th ed. Amer. Soc. Of Agron. Madson. Wisconsion, USA.

Palm, C.A., C.N.,Gachengo, R.J.,Delve, G.,Cadisch, and K.F.Giller, (2001). Organic input, for ferlilty management in tropical agroecoaytems application of an organic recoursed data base. agric. Ecosyst.: Environ 83 (1-2):27:47.

Paudyal, K.R., J.K. Ransom, N.P. Rajbhandari, K. Adhakari, R.V. Gerpacio and P.L. Pingali. (2001). Maize in Nepal; production systems, constraints and priorities for research. Kathmandu: NARC and CIMMYT, pp: 1-56.

Reddy, S. R. (2006). Agronomy of field crops. 2nd Ed. (Kalyani Publishers New Delhi India), pp: 209.

Sarker, M. C.,M. singh,.., and J.Nath, (1992). Influence of foray and manure on soil breccoi and cauliflower to water and nitrogen in the desert herl. Science 31(2):201-205.

Sinkevičienė A. D.Jodaugienė R.Pupalienè M Urbonienè. (2009).The influence of organic mulches on soil properties and crop yield. Agronomy Research, 7: 485-491.

Sedecor, G. W., and Cochran (1980). Statistical methods, 7 th ed., Ox ford and J. B. H. Publ com. 
Sultanpour, P. N. and A. B. Schwab, (1977). A new soil test for simultaneous extraction of macronutrients in alkaline soil. Comm. Soil Sci. and plant Annual, 8, 195.

Zaman W.U. M. Arshad and A. Saleem (2001) Distribution of nitratenitrogen in the soil profile under different irrigation methods. International Journal of Agriculture and Biology,2: 208-209.

الملخص العربح

دراسة تأثير الأحتياجات المائية والتسميد النيتروجيني على إنتاجيه محصول الأرة الصفراء فى الأراضئ والتيدي الطينية.

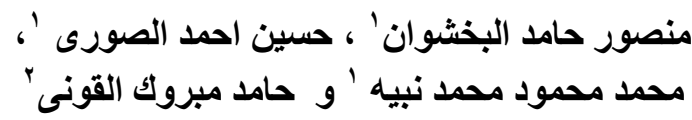

اجريت تجربة حقلية فى موسم VI V. Y بمحطة ابحاث و اختبار ات الجرار ات و الالات الزر اعيةـ

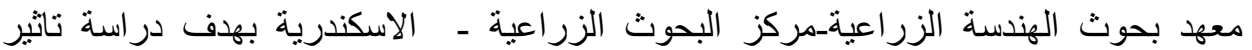

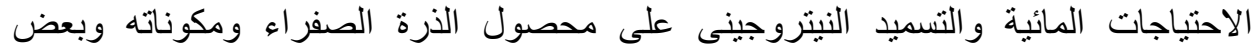
خصائص التربة. تم استخدام تصميم القطع المنشقة فى ثلاث مكرر ات وضعت في ثلاتلث معدلات

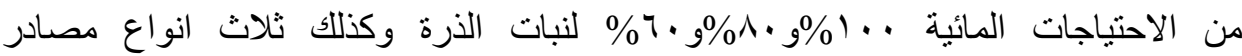

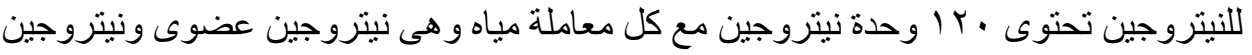

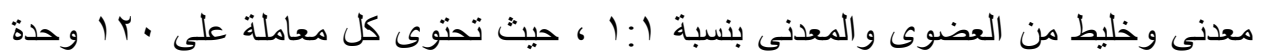
نيتروجين.

بالاضافة لمعاملة الكنترول.تم تطبيق نظام التسميد الموصى به من وزارة الزراعة. اخذت

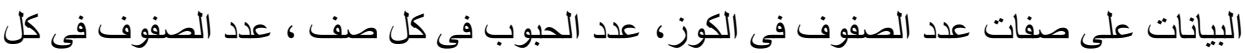
كوز، وزن .ال حبة غعغ بالاضافة الى محصول الحبوب ومحصول القش بالطن للفدان واوضحت النتائج ما يلى: - مانى المعاملة •^\% من الاحتياجات المائية و الخليط من السماد العضوى والمعدنى كانت الأكبر معنوية لمتوسطات قيم كل من النيتروجين الكلى(1.95) و النيتروجين الميسر (126.85) في الثى

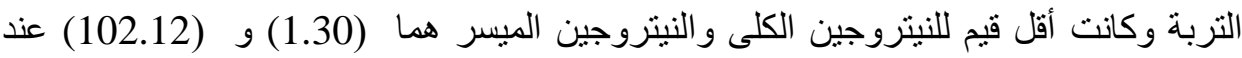

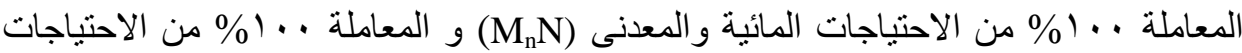




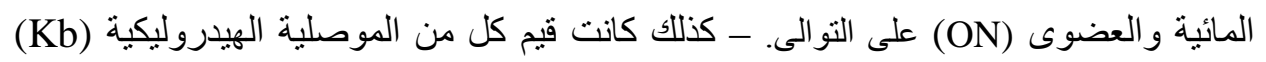

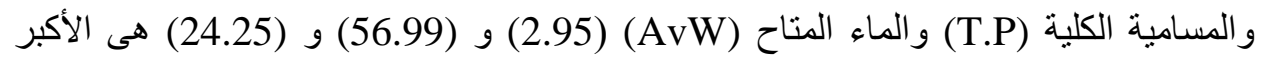

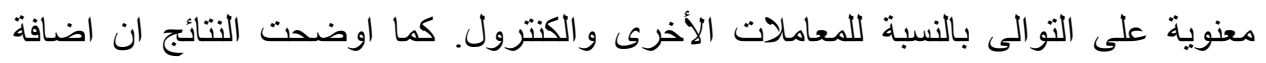

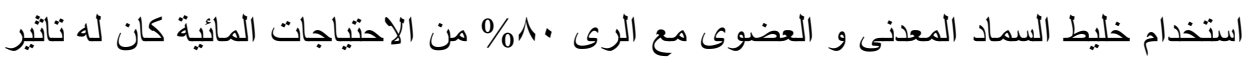

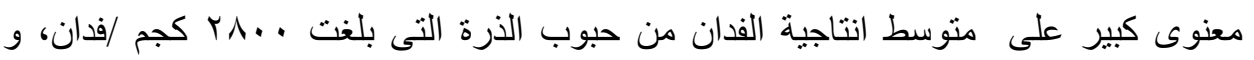

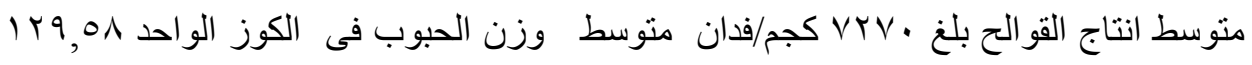

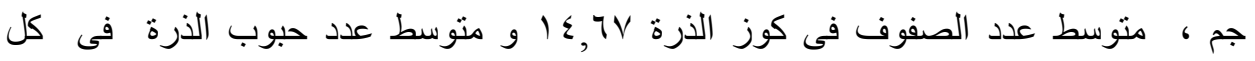

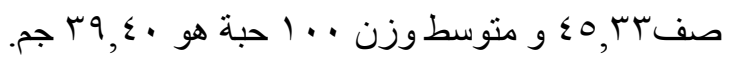

